\title{
A Novel One-Pot and Efficient Procedure for Synthesis of New Fused Uracil Derivatives for DNA Binding
}

\author{
Bothaina A. Mousa1, Ashraf H. Bayoumi2 ${ }^{*}$, Makarem M. Korraa1, Mohamed G. Assy ${ }^{3}$, \\ Samar A. El-Kalyoubi ${ }^{4}$ \\ ${ }^{1}$ Department of Organic Chemistry, Faculty of Pharmacy, Cairo University, Giza, Egypt \\ ${ }^{2}$ Department of Organic Chemistry, Faculty of Pharmacy (Boys), Al-Azhar University, Cairo, Egypt \\ ${ }^{3}$ Department of Organic Chemistry, Faculty of Science, Zagazig University, Zagazig, Egypt \\ ${ }^{4}$ Department of Organic Chemistry, Faculty of Pharmacy (Girls), Al-Azhar University, Cairo, Egypt \\ Email: s.elkalyoubi@hotmail.com
}

Received 22 December 2014; accepted 25 March 2015, published 27 March 2015

Copyright (C) 2015 by authors and Scientific Research Publishing Inc.

This work is licensed under the Creative Commons Attribution International License (CC BY).

http://creativecommons.org/licenses/by/4.0/

(c) (i) Open Access

\begin{abstract}
Hydrazinolysis of 6-chloro-1-methyluracil followed by condensation of the product with different aromatic aldehyde gives the respective hydrazones which undergoes oxidative cyclization using thionyl chloride to obtain pyrazolo[3,4-d]pyrimidines in good yields. On the other hand, nitrosation of 6-aminouracils followed by the reaction with different arylidineanilines gives new xanthine derivatives. Finally, indenopyrrolopyrimidine and indenopteridine are obtained in good yields via the reaction of 6-aminouracils and 5,6-diaminouracil with ninhydrin respectively. The newly synthesized compounds show binding, chelation and fragmentation of the nucleic acid DNA.
\end{abstract}

\section{Keywords}

6-Chloro-1-methyluracil, Pyrazolo[3,4- $d]$ pyrimidines, 6-Aminouracils, Xanthine, Indenopyrrolopyrimidine and Indenopteridine

\section{Introduction}

The importance of fused pyrimidines, common source for the development of new potential therapeutic agents [1] [2], is well known.

Fused pyrimidines continue to attract considerable attention because of their great practical usefulness, primarily due to very wide spectrum of biological activities. This is evident especially from publications of regular 
reviews on the chemistry of systems where the pyrimidine ring is fused to various heterocycles such as purines, quinazolines, pyridopyrimidines, triazolopyrimidines, pyrazolopyrimidines, pyrimidoazepines, furopyrimidines and pyralopyrimidines.

5-Fluorouracil [3]-[5] and methotrexate (MTX) [6]-[8] are the oldest antifolate anticancer drugs [9], which are widely used as chemotherapeutic drugs. They compete with the normal substrates, folic acid and dihydrofolate, for the active site on the enzyme dihydrofolate reductase (DHFR) [10]-[12].

Pyrido[2,3-d]pyrimidines possess dihydrofolate reductase inhibiting and antitumour activity [13]. Similarly, in recent years, considerable attention has been focused on the development of new methodology to synthesize many kinds of pyrazolopyrimidine ring [14]. Indeed, pyrazolopyrimidines [15] [16] and purines [17] represent an important class of heterocyclic compounds having wide range of pharmaceutical and biological activities. Therefore, versatile and widely applicable methods for the synthesis pyrazolopyrimidines and purines are of considerable interest. The existing methods for the preparation of pyrazolopyrimidines are based on heterocyclic hydrazones or hydrazine precursors. Pyrimidines and their derivatives are considered to be important for drugs. A large number of pyrimidine derivatives are reported to exhibit antimycobacterial [18], antitumor [19], antiviral [20], anticancer [21] [22] activities. In the present study, a series of new pyrimidine fused ring analogs have been synthesized and their biological effects are determined.

\section{Material and Methods}

\subsection{Chemistry}

All melting points were determined with an Electrothermal Mel.-Temp. II apparatus and were uncorrected. Element analyses were performed at the Micro Analytical Unit, Chemistry Department, Mansoura University. The infrared (IR) spectra were recorded using potassium bromide disc technique on Nikolet IR 200 FT IR at Pharmaceutical Analytical Unit, Faculty of Pharmacy, Al-Azhar University. The proton nuclear magnetic resonance ( ${ }^{1} \mathrm{H}-\mathrm{NMR}$ ) spectra were recorded on Varian Gemini $300 \mathrm{MHz}$ Spectrometer using DMSO- $\mathrm{d}_{6}$ as a solvent and tetramethylsilane (TMS) as an internal standard (Chemical shift in $\delta$, ppm), Faculty of Science, Chemistry Department, Cairo University. Mass spectra were recorded on DI-50 unit of Shimadzu GC/MS-QP 5050A at the Regional Center for Mycology and Biotechnology at Al-Azhar University. All reactions were monitored by TLC using precoted plastic sheets silica gel (Merck $60 \mathrm{~F}_{254}$ ) and spots were visualized by irradiation with UV light $(254 \mathrm{~nm})$. The used solvent system was chloroform: methanol (9:1) \& ethyl acetate: toluene (1:1).

6-(2-Arylidenehydrazin-1-yl)-1-methyluracils (4a-f) [23]

A mixture of 6-hydrazinyl-1-methyluracil (3) $(0.4 \mathrm{~g}, 2.5 \mathrm{mmol})$ and the appropriate aromatic aldehyde (2.5 $\mathrm{mmol})$ in ethanol $(25 \mathrm{ml})$ was stirred at room temperature for 1.5 - 2 hours. The formed precipitate was filtered, washed with ethanol and crystallized from DMF/ethanol (2:1) into yellow crystals.

Benzaldehyde(3-methyl-2,6-dioxo-1,2,3,6-tetrahydropyrimidin-4-yl)hydrazine 4a [23]: Yield: 81\%, m.p. $=276^{\circ} \mathrm{C}-277^{\circ} \mathrm{C}[23]$.

4-Methoxybenzaldehyde(3-methyl-2,6-dioxo-1,2,3,6-tetrahydropyrimidin-4-yl)hydrazine 4b [23]: Yield: $94 \%$, m.p. $=266^{\circ} \mathrm{C}-268^{\circ} \mathrm{C}[23]$.

4-Hydroxybenzaldehyde(3-methyl-2,6-dioxo-1,2,3,6-tetrahydropyrimidin-4-yl)hydrazine 4c: Yield: 79\%, m.p. $=254^{\circ} \mathrm{C}-256^{\circ} \mathrm{C}$. IR= 3300-3136 overlapped $(\mathrm{OH} \& \mathrm{NH}), 3010$ (CH-arom.), 2840 (CH-aliph.), 1706 (2 C = O), $1644(\mathrm{C}=\mathrm{N}), 832$ (p-substituted phenyl). Anal. Calcd for $\mathrm{C}_{12} \mathrm{H}_{12} \mathrm{~N}_{4} \mathrm{O}_{3}(260.25)$, Calcd.: C, 55.38, H, 4.65, N, 21.35, Found: C, 55.42, H, 4.70, N, 21.65.

3-Chlorobenzaldehyde(3-methyl-2,6-dioxo-1,2,3,6-tetrahydropyrimidin-4-yl)hydrazine 4d: Yield: 91\%, m.p. $=261^{\circ} \mathrm{C}-263^{\circ} \mathrm{C}$. IR= $3252(\mathrm{NH}), 3102(\mathrm{CH}-a r o m),. 2900(\mathrm{CH}$ aliph.), $1728(2 \mathrm{C}=\mathrm{O}), 1636(\mathrm{C}=\mathrm{N}), 700$ \& 786 (m-substituted phenyl). Anal. Calcd for $\mathrm{C}_{12} \mathrm{H}_{11} \mathrm{ClN}_{4} \mathrm{O}_{2}$ (278.69), Calcd.: C, 51.72, H, 3.98, N, 20.10, Found: C, 51.41, H, 4.45, N, 20.28.

4-Chlorobenzaldehyde(3-methyl-2,6-dioxo-1,2,3,6-tetrahydropyrimidin-4-yl)hydrazine 4e [23]: Yield: $92 \%$, m.p. $=273^{\circ} \mathrm{C}-275^{\circ} \mathrm{C}[23]$.

4-Hydroxy-3-methoxybenzaldehyde(3-methyl-2,6-dioxo-1,2,3,6-tetrahydropyrimidin-4-yl) hydrazine 4f: Yield: 82\%, m.p. $=250^{\circ} \mathrm{C}-252^{\circ} \mathrm{C}$. IR $=3494(\mathrm{OH}), 3180(\mathrm{NH}), 3036$ (CH-arom.), $2920(\mathrm{CH}$ aliph.), 1708 (2 C $=\mathrm{O}), 1644(\mathrm{C}=\mathrm{N}), 820,760$ (substituted phenyl). Anal. Calcd for $\mathrm{C}_{13} \mathrm{H}_{14} \mathrm{~N}_{4} \mathrm{O}_{4}$ (290.27), Calcd.: C, 53.79, H, 4.86, N, 19.30, Found: C, 53.60, H, 4.53, N, 19.10.

3-Aryl-7-methyl-1H-pyrazolo[3,4-d]pyrimidine-4,6(5H,7H)-diones (5a-f) 
A mixture of the appropriate 6-(2-arylidenehydrazin-1-yl)-1-methyluracil (4a-f) (1.2 mmol) and excess of thionyl chloride $(2 \mathrm{ml})$ was heated under reflux for 5 - 7 minutes. The excess thionyl chloride was evaporated under reduced pressure. An adequate amount of aqueous ammonia solution was added to the residue. The formed precipitate was filtered, washed with ethanol and crystallized from DMF/ethanol (3:1).

7-Methyl-3-phenyl-1H-pyrazolo[3,4-d]pyrimidine-4,6(5H,7H)-dione 5a: Yield: 69\%, m.p. $=212^{\circ} \mathrm{C}-$ $214^{\circ} \mathrm{C} . \mathrm{IR}=3172$ (NH), 3050 (CH arom.), 2940, 2868 (CH aliph.), 1716, 1672 (2 C = O), 1563 (C = N) \& (C = C). ${ }^{1} \mathrm{H}-\mathrm{NMR}$ (DMSO-d ${ }_{6}$ ) $\delta$ ppm: 11.80 (bs, 1H, NH), 10.86 (s, 1H, NH), 8.06 (s, 2H, arom.), 7.48 (s, 3H, arom.), 3.52 (s, 3H, $\mathrm{NCH}_{3}$ ). Anal. Calcd for $\mathrm{C}_{12} \mathrm{H}_{10} \mathrm{~N}_{4} \mathrm{O}_{2}$ (242.23), Calcd.: C, 59.50, H, 4.16, N, 23.13, Found: C, 58.96, H, 4.35, N, 23.01.

3-(4-Methoxyphenyl)-7-methyl-1H-pyrazolo[3,4-d]pyrimidine-4,6(5H,7H)-dione 5b: Yield: 54\%, m.p. = $215^{\circ} \mathrm{C}-217^{\circ} \mathrm{C} . \mathrm{IR}=3173(\mathrm{NH}), 3052$ (CH arom.), 2943, 2815 (CH aliph.), 1683 (br, $\left.2 \mathrm{C}=\mathrm{O}\right), 1563(\mathrm{C}=\mathrm{N}) \&$ $(\mathrm{C}=\mathrm{C}), 844$ (p-substituted phenyl). MS: $m / z(\%)=272\left(\mathrm{M}^{+}, 2.52\right), 85(100)$. Anal. Calcd for $\mathrm{C}_{13} \mathrm{H}_{12} \mathrm{~N}_{4} \mathrm{O}_{3}$ (272.25), Calcd.: C, 57.35, H, 4.44, N, 20.58, Found: C, 57.01, H, 4.44, N, 20.32.

3-(4-Hydroxyphenyl)-7-methyl-1H-pyrazolo[3,4-d]pyrimidine-4,6(5H,7H)-dione 5c: Yield: 51\%, m.p. = $210^{\circ} \mathrm{C}-212^{\circ} \mathrm{C}$. IR = $3430(\mathrm{OH}), 3174(\mathrm{NH}), 3053$ (CH arom.), 2939, 2817 (CH aliph.), 1697 (2 C = O), 1583 (C $=\mathrm{N})$ \& $(\mathrm{C}=\mathrm{C}), 840$ (p-substituted phenyl). Anal. Calcd for $\mathrm{C}_{12} \mathrm{H}_{10} \mathrm{~N}_{4} \mathrm{O}_{3}$ (258.23), Calcd.: C, 55.81, H, 3.90, N, 21.70, Found: C, 55.56, H, 3.79, N, 21.41.

3-(3-Chlorophenyl)-7-methyl-1H-pyrazolo[3,4-d]pyrimidine-4,6(5H,7H)-dione 5d: Yield: 67\%, m.p. = $239^{\circ} \mathrm{C}-241^{\circ} \mathrm{C} . \mathrm{IR}=3171(\mathrm{NH}), 3051$ (CH arom.), 2920, $2853(\mathrm{CH}$ aliph.), 1716, $1676(2 \mathrm{C}=\mathrm{O}), 1564(\mathrm{C}=\mathrm{N})$ \& $(\mathrm{C}=\mathrm{C}), 756,668$ (m-substituted phenyl). Anal. Calcd for $\mathrm{C}_{12} \mathrm{H}_{9} \mathrm{ClN}_{4} \mathrm{O}_{2}$ (276.67), Calcd.: C, 52.09, H, 3.28, N, 20.25, Found: C, 51.65, H, 3.68, N, 20.40.

3-(4-Chlorophenyl)-7-methyl-1H-pyrazolo[3,4-d]pyrimidine-4,6(5H,7H)-dione 5e: Yield: 72\%, m.p. = $195^{\circ} \mathrm{C}-197^{\circ} \mathrm{C} . \mathrm{IR}=3171(\mathrm{NH}), 3050$ (CH arom.), 2936, 2854 (CH aliph.), 1713, $1670(2 \mathrm{C}=\mathrm{O}), 1565$ (C = N) \& $(\mathrm{C}=\mathrm{C}), 824$ (p-substituted phenyl). Anal. Calcd for $\mathrm{C}_{12} \mathrm{H}_{9} \mathrm{ClN}_{4} \mathrm{O}_{2}$ (276.67), Calcd.: C, 52.09, H, 3.28, N, 20.25, Found: C, 52.09, H, 3.18, N, 20.08.

3-(4-Hydroxy-3-methoxyphenyl)-7-methyl-1H-pyrazolo[3,4-d]pyrimidine-4,6(5H,7H)-dione 5f: Yield: $63 \%$, m.p. $=192^{\circ} \mathrm{C}-194^{\circ} \mathrm{C} . \mathrm{IR}=3426(\mathrm{OH}), 3172(\mathrm{NH}), 3051$ (CH arom.), 2930, 2879 (CH aliph.), 1721, 1671 (2 $\mathrm{C}=\mathrm{O}), 1561(\mathrm{C}=\mathrm{C}), 843$, 665 (substituted phenyl). Anal. Calcd for $\mathrm{C}_{13} \mathrm{H}_{12} \mathrm{~N}_{4} \mathrm{O}_{4}$ (288.25), Calcd.: C, 54.17, H, 4.20, N, 19.44, Found: C, 54.52, H, 4.02, N, 19.31.

\section{6-Amino-1-[(2-chlorophenyl)methyl]-5-nitrosouracil (7)}

A mixture of 6-amino-1-[(2-chlorophenyl)methyl]uracil (6) (2.0 g, $7.9 \mathrm{mmol})$ was suspended in water (90 ml) in the presence of glacial acetic acid $(0.4 \mathrm{ml})$ and sodium nitrite $(0.54 \mathrm{~g}, 7.9 \mathrm{mmol})$ in water $(5 \mathrm{ml})$ was stirred at room temperature for $1 / 2 \mathrm{hr}$. The formed cherry red precipitate was filtered, washed with ethanol and crystallized from ethanol into violet crystals 7, Yield: 95\%, m.p. $=235^{\circ} \mathrm{C}-237^{\circ} \mathrm{C} . \mathrm{IR}=3479(\mathrm{~N}-\mathrm{OH}), 3338,3251(\mathrm{NH} 2$ \& NH), 3077 (CH arom.), 2979, 2804 (CH aliph.), 1690, 1638 (2 C = O), 751 (o-substituted phenyl). Anal. Calcd for $\mathrm{C}_{11} \mathrm{H}_{9} \mathrm{ClN}_{4} \mathrm{O}_{3}$ (280.66), Calcd.: C, 47.07, H, 3.23, N, 19.96, Found: C, 47.03, H, 3.20, N, 19.72.

\section{8-Aryl-3-[(2-chlorophenyl)methyl]-7-hydroxyxanthines (8a-d)}

A mixture of 6-amino-1-[(2-chlorophenyl)methyl]-5-nitrosouracil (7) (0.3 g, $1.06 \mathrm{mmol})$ and the appropriate $\mathrm{N}$-arylidene aniline $(1.06 \mathrm{mmol})$ in glacial acetic acid $(3 \mathrm{ml})$ was heated under reflux for 8 - 10 hours. After cooling, the formed precipitate was filtered, washed with ethanol and crystallized from DMF/ethanol (2:1) into colourless crystals.

3-(2-Chlorobenzyl)-8-(4-chlorophenyl)-7-hydroxyxanthine (8a): Yield: 86\%, m.p. $=>330^{\circ} \mathrm{C} . \mathrm{IR}=3300$ 2900 (br, OH), 3143 (NH), 3042 (CH arom.), 2823 (CH aliph.), 1695 (C = O), 1548 (C = C), 838 (p-substituted phenyl), 747 (o-substituted phenyl). ${ }^{1} \mathrm{H}-\mathrm{NMR}\left(\mathrm{DMSO}-\mathrm{d}_{6}\right) \delta 14.01$ (s, 1H, OH, exchangeable), 11.33 (s, $1 \mathrm{H}, \mathrm{NH}$, exchangeable), 8.06 - 8.04 (d, 2H, arom.), 7.56 - 7.52 (d, 2H, arom.), 7.49 (d, 1H, arom.), 7.33 - 7.22 (m, $2 \mathrm{H}$, arom.), 7.08 - 7.05 (d, $1 \mathrm{H}$, arom.), 5.24 (s, 2H, $\mathrm{NCH}_{2}$ ). Anal. Calcd for $\mathrm{C}_{18} \mathrm{H}_{12} \mathrm{Cl}_{2} \mathrm{~N}_{4} \mathrm{O}_{3}$ (403.21), Calcd.: C, 53.62, H, 3.00, N, 13.89, Found: C, 53.81, H, 3.15, N, 13.80 .

8-(4-Bromophenyl)-3-(2-chlorobenzyl)-7-hydroxyxanthine (8b): Yield: 81\%, m.p. $=>330^{\circ} \mathrm{C} . \mathrm{IR}=3300-$ 2900 (br, OH), 3150 (NH), 3024 (CH arom.), 2940, 2819 (CH aliph.), 1697 (C = O), 1552 (C = C), 835 (p-substituted phenyl), 749 (o-substituted phenyl). Anal. Calcd for $\mathrm{C}_{18} \mathrm{H}_{12} \mathrm{BrClN}_{4} \mathrm{O}_{3}$ (447.66), Calcd.: C, 48.29, H, 2.70 , N, 12.52, Found: C, 48.49, H, 3.20, N, 12.86 .

3-(2-Chlorobenzyl)-7-hydroxy-8-(4-nitrophenyl)xanthine 8c: Yield: 89\%, m.p. $=>330^{\circ} \mathrm{C}$. IR = 3300 3000 (br, OH), 3147 (NH), 3025 (CH arom.), 2925, 2850 (CH aliph.), 1693 (C = O), 1559 (C = C), 1520, 1343 
( $\mathrm{NO}_{2}$ ), 859 (p-substituted phenyl), 752 (o-substituted phenyl). Anal. Calcd for $\mathrm{C}_{18} \mathrm{H}_{12} \mathrm{ClN}_{5} \mathrm{O}_{5}$ (413.77), Calcd.: C, 52.25, H, 2.92, N, 16.93, Found: C, 52.40, H, 2.90, N, 17.22.

3-(2-Chlorobenzyl)-8-(4-fluorophenyl)-7-hydroxyxanthine 8d: Yield: $63 \%$, m.p. $=>330^{\circ} \mathrm{C} . \mathrm{IR}=3300$ 3000 (br, OH), 3155 (NH), 3025 (CH arom.), 2923, 2849 (CH aliph.), 1695 (C = O), 1562 (C = C), 843 (p-substituted phenyl), 747 (o-substituted phenyl). ${ }^{1} \mathrm{H}-\mathrm{NMR}$ (DMSO-d $\left.\mathrm{d}_{6}\right) \delta 13.98(\mathrm{~s}, 1 \mathrm{H}, \mathrm{OH}), 11.28(\mathrm{~s}, 1 \mathrm{H}, \mathrm{NH})$, 8.08 - 8.04 (m, 2H, arom.), 7.50 - 7.47 (d, 1H, arom.), 7.33 - 7.24 (m, 4H, arom.), $7.04-7.02$ (d, $1 \mathrm{H}$, arom.), $5.23\left(\mathrm{~s}, 2 \mathrm{H}, \mathrm{NCH}_{2}\right)$. MS: $\mathrm{m} / \mathrm{z}(\%)=388\left(\mathrm{M}^{+}+2,1.8\right), 386\left(\mathrm{M}^{+}, 4.53\right), 125(100)$. Anal. Calcd for $\mathrm{C}_{18} \mathrm{H}_{12} \mathrm{ClFN}_{4} \mathrm{O}_{3}$ (386.76), Calcd.: C, 55.90, H, 3.13, N, 14.49, Found: C, 56.06, H, 3.50, N, 14.14.

1-Benzyl[or(2-chlorophenyl)methyl]-4b,9b-dihydroxy-9b,10-dihydroindeno[2',1':4,5] pyrrolo[2,3d]pyrimidine-2,4,5(1H,3H,4bH)-triones (9a,b)

A mixture of the appropriate 6-amino-1-benzyl-[or (2-chlorophenyl)methyl]uracil (6a,b) $(1.2 \mathrm{mmol})$ and ninhydrin ( $0.2 \mathrm{~g}, 1.2 \mathrm{mmol})$ in ethanol $(20 \mathrm{ml})$ was heated under reflux for 1 hour. The formed precipitate on hot was filtered, washed with ethanol and crystallized from ethanol.

1-Benzyl-4b,9b-dihydroxy-9b,10-dihydroindeno[2',1':4,5]pyrrolo[2,3-d]pyrimidine-2,4,5

(1H,3H,4bH)-trione 9a: Yield: 68\%, m.p. $=270^{\circ} \mathrm{C}-272^{\circ} \mathrm{C} . \mathrm{IR}=3544-3000(\mathrm{br}, \mathrm{OH}), 3286,3182(\mathrm{NH}), 3025$ (CH arom.), 2922, 2845 (CH aliph.), 1709, 1656 ( $\mathrm{C}=\mathrm{O}$ ), 1553 (C = C), 769, 702 (monosubstituted phenyl). ${ }^{1} \mathrm{H}-\mathrm{NMR}$ (DMSO-d 6 ) $\delta 10.39$ (s, 1H, NH), 9.37 (s, 1H, NH), $7.85-7.80(\mathrm{~m}, 2 \mathrm{H}$, arom.), $7.70-7.68$ (d, $1 \mathrm{H}$, arom.), 7.59 - 7.57 (d, 1H, arom.), 7.29 - 7.27 (m, 3H, arom.), 7.18 - 7.16 (m, 2H, arom.), 6.81 (s, 1H, OH), 5.98 (s, $1 \mathrm{H}, \mathrm{OH}), 4.94-4.90$ (d, $\left.1 \mathrm{H}, \mathrm{NCH}_{2}\right), 4.80$ - $4.67\left(\mathrm{~d}, 1 \mathrm{H}, \mathrm{NCH}_{2}\right.$ ). Anal. Calcd for $\mathrm{C}_{20} \mathrm{H}_{15} \mathrm{~N}_{3} \mathrm{O}_{5}$ (377.35) Calcd.: C, 63.66, H, 4.01, N, 11.14, Found: C, 63.46, H, 4.10, N, 10.82.

1-(2-Chlorophenyl)methyl-4b,9b-dihydroxy-9b,10-dihydroindeno $\left[2^{\prime}, 1^{\prime}: 4,5\right]$ pyrrolo $[2,3-d]$ pyrimidine2,4,5(1H,3H,4bH)-trione 9b: Yield: 71\%, m.p. $=272^{\circ} \mathrm{C}-273^{\circ} \mathrm{C}$. IR = $3600-2900(\mathrm{br}, \mathrm{OH}), 3286,3182(\mathrm{NH})$, 3025 (CH arom.), 2844 (CH aliph.), 1712, 1661 (C = O), 1560 (C = C), 762 (o-substituted phenyl). ${ }^{1} \mathrm{H}-\mathrm{NMR}$ (DMSO-d $\left.\mathrm{d}_{6}\right) \delta 10.48$ (s, 1H, NH, exchangeable), 9.41 (s, 1H, NH, exchangeable), 7.79 - 7.77 (d, 2H, arom.), 7.72 - 7.69 (d, 1H, arom.), 7.60 - 7.49 (m, 2H, arom.), 7.35 - 7.21 (m, 2H, arom.), 6.83 - 6.80 (d, 1H, arom.), 6.78 (s, $1 \mathrm{H}, \mathrm{OH}$, exchangeable), 5.97 (s, $1 \mathrm{H}, \mathrm{OH}$, exchangeable), $5.04-4.98\left(\mathrm{~d}, 1 \mathrm{H}, \mathrm{NCH}_{2}\right), 4.81-4.75\left(\mathrm{~d}, 1 \mathrm{H}, \mathrm{NCH}_{2}\right)$. MS: $m / z(\%)=414\left(\mathrm{M}^{+}+2,0.2\right), 412\left(\mathrm{M}^{+}, 0.47\right),\left[395(1.2), 393\left(3.25, \mathrm{M}^{+}-\mathrm{H}_{2} \mathrm{O}\right)\right], 44(100)$. Anal. Calcd for $\mathrm{C}_{20} \mathrm{H}_{14} \mathrm{ClN}_{3} \mathrm{O}_{5}$ (411.79) Calcd.: C, 58.33, H, 3.43, N, 10.20, Found: C, 58.31, H, 3.42, N, 9.87.

1,3-Dimethyl-2H-indeno[2,1-g]pteridine-2,4,6-(1H,3H)-trione (11)

Two methods were applied for the synthesis of $\mathbf{1 1}$ :

A) A mixture of 5,6-diamino-1,3-dimethyluracil hydrochloride (10) $(0.2 \mathrm{~g}, 1.00 \mathrm{mmol})$ and ninhydrin $(0.18 \mathrm{~g}$, $1.00 \mathrm{mmol})$ in ethanol $(10 \mathrm{ml})$ and drops of TEA was added to adjust $\mathrm{pH}=8$. The reaction mixture was stirred at room temperature for 30 minutes. The formed precipitate was filtered, washed with ethanol and crystallized from ethanol into yellow crystals.

B) A mixture of 5,6-diamino-1,3-dimethyluracil hydrochloride (10) $(0.2 \mathrm{~g}, 1.00 \mathrm{mmol})$ and ninhydrin $(0.18 \mathrm{~g}$, $1.00 \mathrm{mmol})$ in water $(15 \mathrm{ml})$ and few drops of ammonium hydroxide solution was added to adjust $\mathrm{pH}=8$ was stirred at room temperature for 1 hour. The formed precipitate was filtered, washed with ethanol and crystallized from ethanol.

Yield: A 60.7\%, B 59\%, m.p. $=>320^{\circ} \mathrm{C}$. IR $=3066$ ( $\mathrm{CH}$ arom.), 2934, $2870(\mathrm{CH}$ aliph.), 1723, $1672(\mathrm{C}=\mathrm{O})$, $1567(\mathrm{C}=\mathrm{N}), 1508(\mathrm{C}=\mathrm{C}) .{ }^{1} \mathrm{H}-\mathrm{NMR}$ (DMSO-d $\left.\mathrm{d}_{6}\right) \delta 7.97-7.95$ (d, 1H, arom.), 7.85 - 7.81 (m, 2H, arom.), 7.74 - 7.69 (d, 1H, arom.), 3.66 (s, 3H, $\left.\mathrm{NCH}_{3}\right), 3.41$ (s, 3H, $\mathrm{NCH}_{3}$ ). MS: $\mathrm{m} / \mathrm{z}(\%)=294\left(\mathrm{M}^{+}, 100\right)$. Anal. Calcd for $\mathrm{C}_{15} \mathrm{H}_{10} \mathrm{~N}_{4} \mathrm{O}_{3}$ (294.26) Calcd.: C, 61.22, H, 3.43, N, 19.04, Found: C, 61.03, H, 3.06, N, 18.60.

\subsection{Biological Evaluation}

\subsubsection{Nucleic Acids Preparation}

For extraction of genomic DNA, yeast cells were washed with cold phosphate borate sodium chloride (PBS) buffer and lysed in a buffer containing $50 \mathrm{mM}$ Tris- $\mathrm{HCl}$ (pH 8.0), $1 \mathrm{mM}$ EDTA, 0.2\% Triton X-100 for 20 min at $4^{\circ} \mathrm{C}$. After centrifugation at $14,000 \mathrm{rpm}$ for $15 \mathrm{~min}$, the supernatant was treated with proteinase $\mathrm{K}(0.5 \mathrm{mg} / \mathrm{ml})$ and $1 \%$ SDS for $1 \mathrm{~h}$ at $50^{\circ} \mathrm{C}$. DNA was extracted twice with buffered phenol/chloroform and precipitated with $140 \mathrm{mM} \mathrm{NaCl}$ and 2 volumes of ethanol at $-20^{\circ} \mathrm{C}$ overnight. DNA precipitates were washed twice with $70 \%$ ethanol, air-dried and dissolved in TE buffer, and treated for $1 \mathrm{~h}$ at $37^{\circ} \mathrm{C}$ with RNase A according to reported 
method [24]. Finally, DNA preparations were electrophoresed in 1\% agarose gels.

\subsubsection{Agrose Gel Preparation and Visualization of DNA}

$1 \%$ agarose gel was prepared by adding $1 \mathrm{gm}$ ultra agarose to $100 \mathrm{ml}$ Tris-Acetate-EDTA (TAE) buffer and heated in a microwave oven then cooled to $\sim 60^{\circ} \mathrm{C}$ before pouring in gel tray.

Examination of the gel was carried out using ultraviolet illuminated box. Ethidium bromide $(0.1 \mathrm{mg} / \mathrm{ml})$ solution was used to stain the nucleic acid (DNA bands) in the gel as it intercalates between DNA bases and give florescence. The gel was photographed using polarized camera.

\subsubsection{Nucleic Acid Affinity, Binding and Fragmentation Assay}

The test compounds were dissolved in DMSO at $20 \mu \mathrm{g} / \mu \mathrm{l}$ concentrations, mixed with $2 \mu \mathrm{g} / \mu \mathrm{l} \mathrm{DNA}$ and incubated at room temperature for 2 hrs. The mixtures were mixed with the gel loading buffer and then electrophoresed in the agarose gel $(1 \% \mathrm{w} / \mathrm{v})$ at $80 \mathrm{~V}$ for $1.5 \mathrm{hrs}$. As positive control for affinity, binding and fragmentation, methotrexate $(20 \mu \mathrm{g} / \mu \mathrm{l})$ was mixed with DNA, and as negative control DMSO was mixed with equal amount of DNA. After running, agarose gels were stained with ethidium bromide and visualized using polarized camera.

\section{Results and Discussion}

\subsection{Chemistry}

6-Chlorouracils (1) were prepared by the alkaline hydrolysis of 2,4,6-trichloropyrimidines [25] [26]. Methylation of 6-chlorouracil (1) was carried out with methyl iodide in the presence of potassium carbonate applying a reported procedure [27]. 6-Hydrazinyl-1-methyluracil (3) [28] was prepared in a good yield by the reaction of 6-chloro-1-methyluracil (2) with alcoholic hydrazine hydrate at room temperature following a reported method [23]. In this investigation the title compounds were furnished through the hydrazinolysis of 6-chloro-1-methyluracil (2). Condensation of the hydrazinylpyrimidine 3 with aromatic aldehydes gave the respective hydrazones 4a-f. Oxidative cyclization of $\mathbf{4}$ using thionyl chloride produced pyrazolopyrimidines $\mathbf{5 a - f}$ in good yields.<smiles>CO[AsH3](C)(C)O[Na]</smiles>

1<smiles>Cn1c(Cl)cc(=O)[nH]c1=O</smiles>

2<smiles>[R]c1ccc(C2NNc3c2c(=O)[nH]c(=O)n3C)cc1</smiles>

5a- $f$<smiles>NOCCON</smiles><smiles>Cn1c(NN)cc(=O)[nH]c1=O</smiles>

3<smiles>[R]c1cccc(/C=N/Nc2cc(=O)[nH]c(=O)n2C)c1</smiles>

Thus, refluxing of compounds 4a-f with thionyl chloride resulted in intramolecular cyclization affording pyrazolopyrimidines 5a-f presumably via the formation of the 5-chlorosulfinyl derivatives A which loses (SO) group and $\mathrm{HCl}$ to form Xa-f. The structure of target compounds was confirmed by element analysis in addition to IR, ${ }^{1} \mathrm{H}-\mathrm{NMR}$ spectral data. 


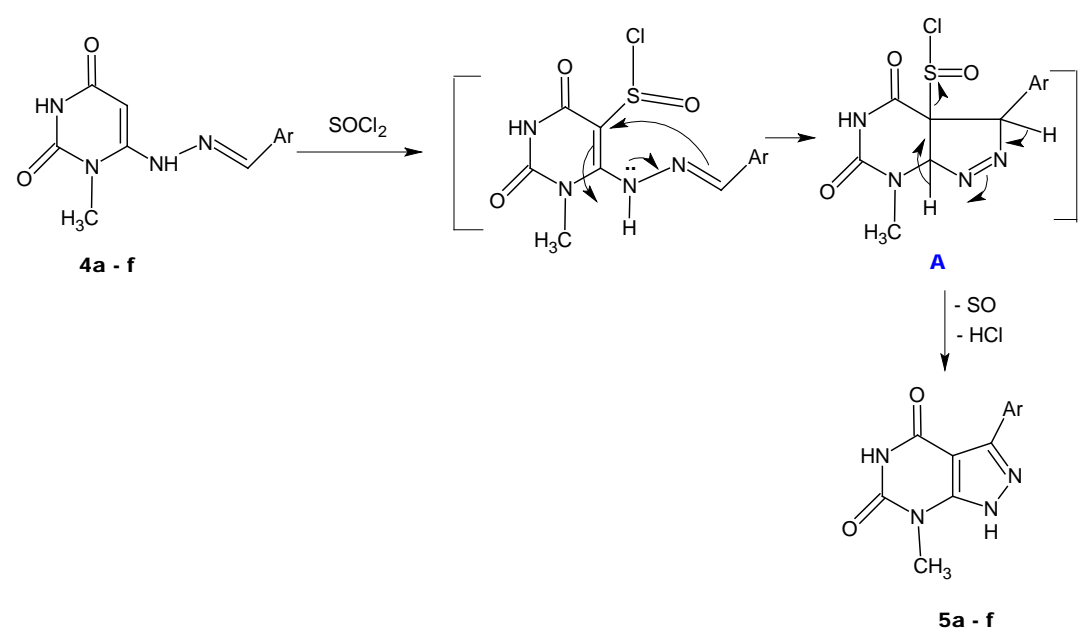

Compounds 6a,b were prepared in good yields by the condensation of ethyl cyanoacetate with N-benzyluea [29] or N-[(2-chlorophenyl)methyl]urea [30] in sodium ethoxide or methoxide. In this work, it was in need to prepare first the unavailable starting material, 6-amino-1-[(2-chlorophenyl)methyl]-5-nitrosouracil (7). Reaction of 6-amino-1-[(2-chlorophenyl)methyl]uracil (6b) with aqueous sodium nitrite in the presence of acetic acid afforded a high yield of the coloured nitroso derivative 7 [31]. Thus, reaction of 7 with different arylidene aniline in acetic acid took place by the elimination of aniline to give 8a-d.

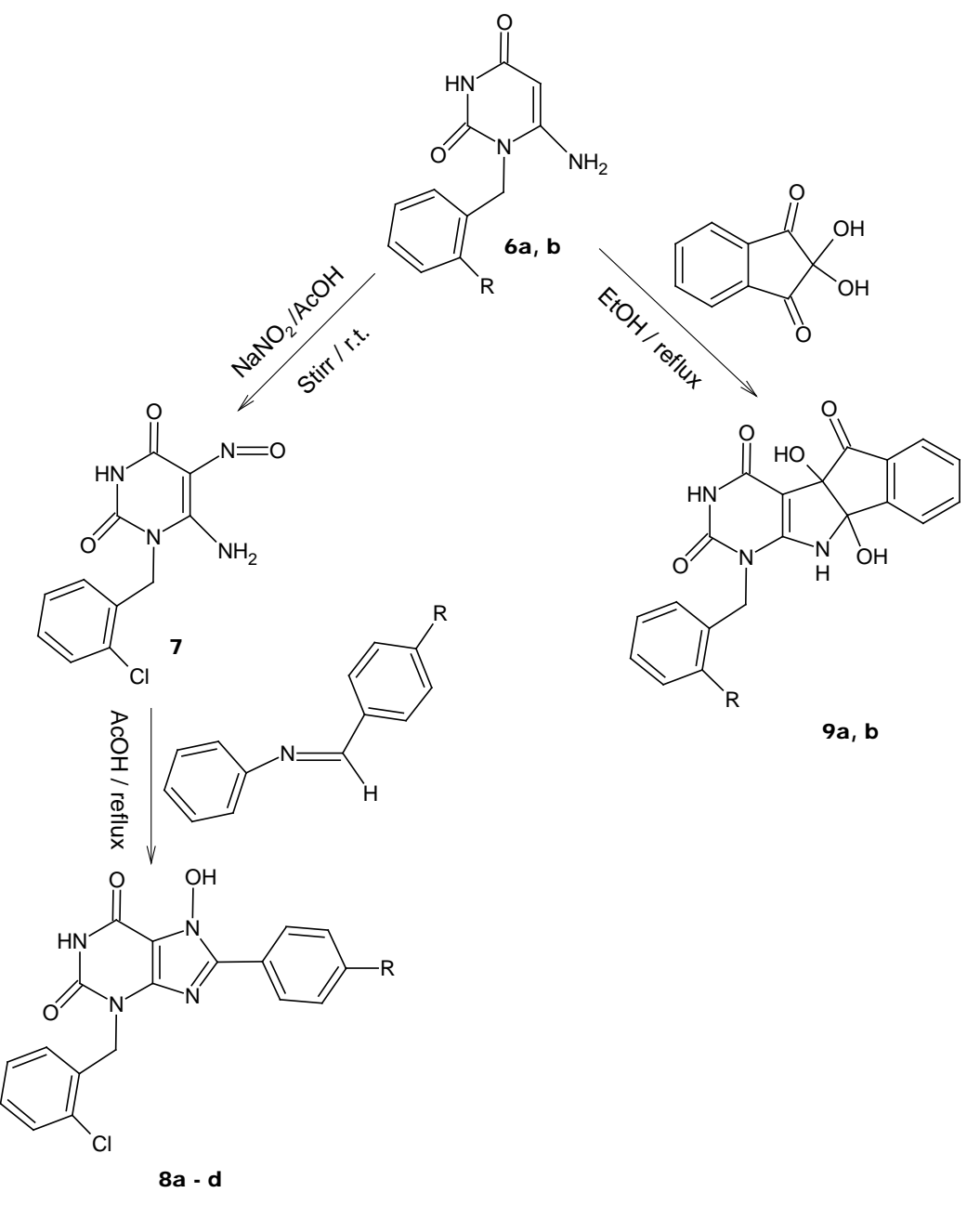


An expected mechanism might be as follows:<smiles>Nc1c([N+](=O)[O-])c(=O)[nH]c(=O)n1Cc1ccccc1Cl</smiles>

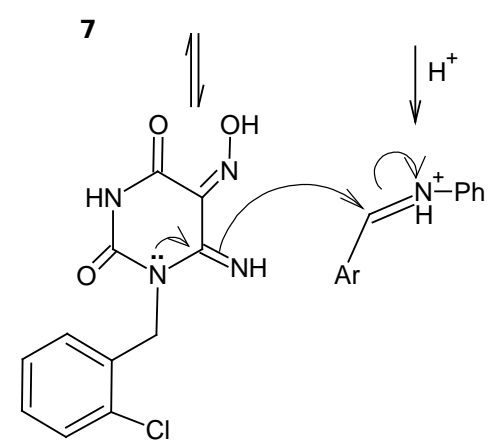

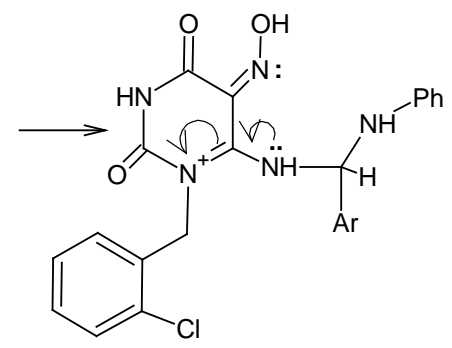

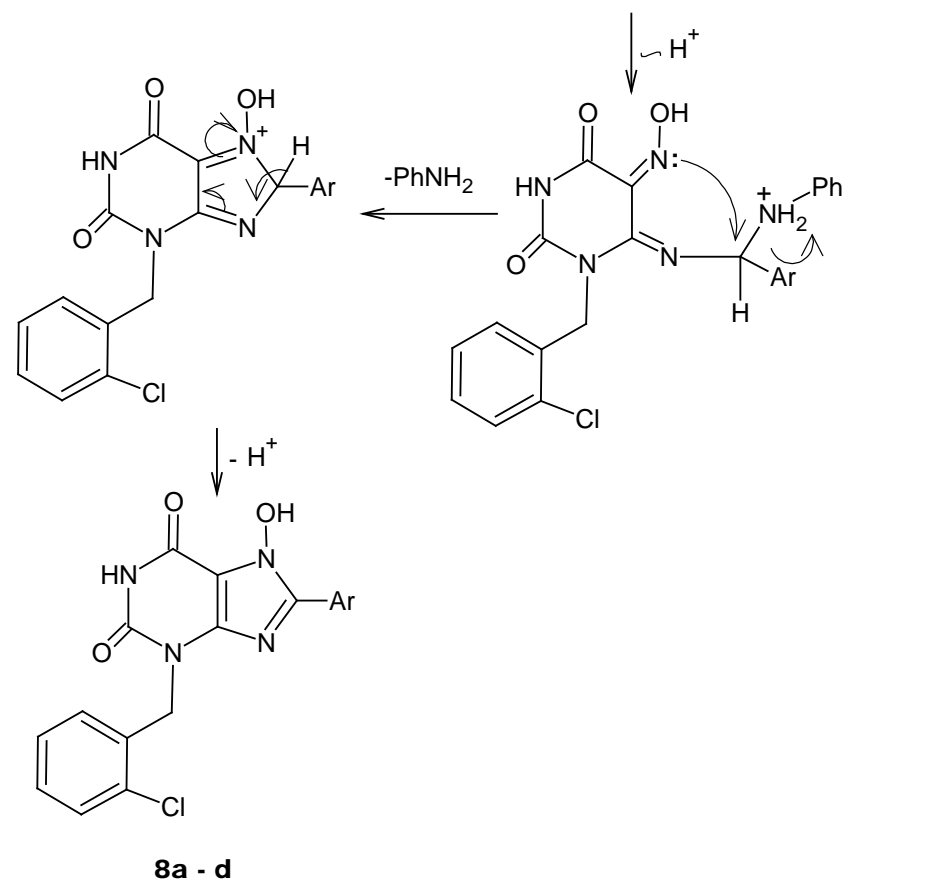

On the other hand, the reaction of aminouracils $\mathbf{6 a}, \mathbf{b}$ by refluxing with ninhydrin in DMF resulted in the formation of indenopyrrolopyrimidines $\mathbf{9 a , b}$ in a moderate yields. It was reported that the 2-position of the ninhydrin is more reactive towards nitrogen [32], oxygen [32] [33] and carbon based nucleophiles [32]-[34]. The cyclization affording 9a,b presumably occurred via the formation of nonisolable acyclic intermediate. The latter might be formed via the attack of the more nucleophilic carbon at 5-position of uracil to the more reactive center at 2-position of ninhydrin. Cyclization could be affected via the addition of the amino group to the carbonyl at 1-position of ninhydrin moiety affording the final product 9a,b. ${ }^{1} \mathrm{H}-\mathrm{NMR}$ showed the two benzylic hydrogens as two doublets at $\delta=4.94-4.67 \mathrm{ppm}$ which indicated that they were not magnetically equivalent. This observation may be attributed to the presence of stereoisomers resulted from the two asymmetric carbons at $4 \mathrm{~b}$ and $9 \mathrm{~b}$ positions. 


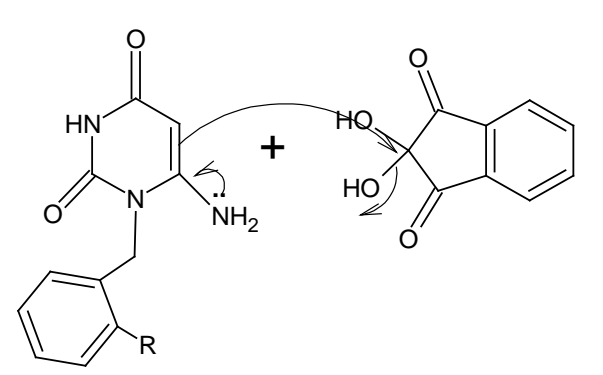

$6 a, b$

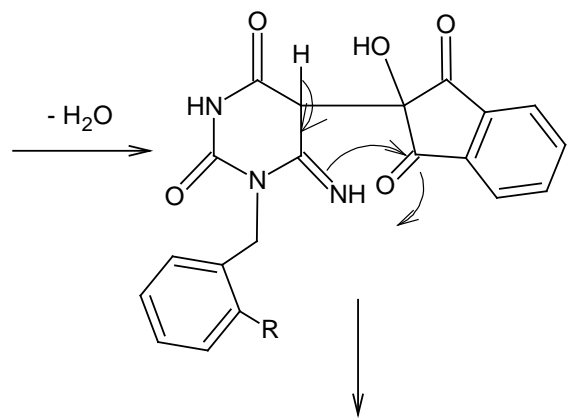<smiles>[R]c1ccccc1Cn1c2c(c(=O)[nH]c1=O)C1(O)C(=O)c3ccccc3C1(O)N2</smiles>

9a, b

The project now directed towards the possible utility of diaminouracils for the synthesis of the title compound 11. Thus, the reaction of 5,6-diamino-1,3-dimethyluracil hydrochloride (10) [29] [35]-[37] with ninhydrin in the presence of triethylamine or ammonium hydroxide afforded the title compound $\mathbf{1 1 .}$<smiles>CCO[C@@H](OC)C(=O)ON</smiles>

10<smiles>Cn1c(=O)c2nc3c(nc2n(C)c1=O)-c1ccccc1C3=O</smiles>

11

The formation of $\mathbf{1 1}$ from the aminouracil $\mathbf{1 0}$ and ninhydrin may be proceed through first condensation between the more reactive $\mathrm{NH}_{2}$ at 5-position with the more electrophilic center at $\mathrm{C}-2$ of ninhydrin. Attack of the less reactive $\mathrm{NH}_{2}$ group at 6-position to one of the $\mathrm{C}=\mathrm{O}$ groups of the reagent afforded the cyclized tautomer $\mathbf{B}$ which was stabilized by loss of $\mathrm{H}_{2} \mathrm{O}$ to give 11 .<smiles>Cn1c(N)c(N)c(=O)n(C)c1=O</smiles>

10<smiles>Cn1c(=O)c2nc3c(nc2n(C)c1=O)-c1ccccc1C3=O</smiles>

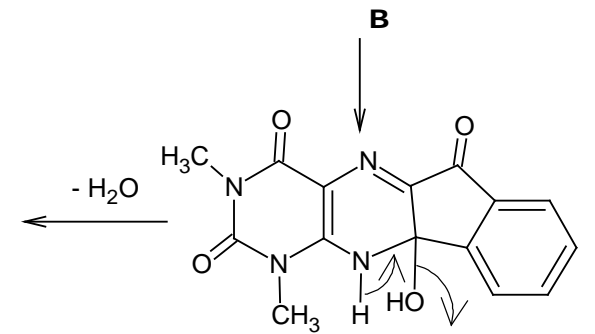




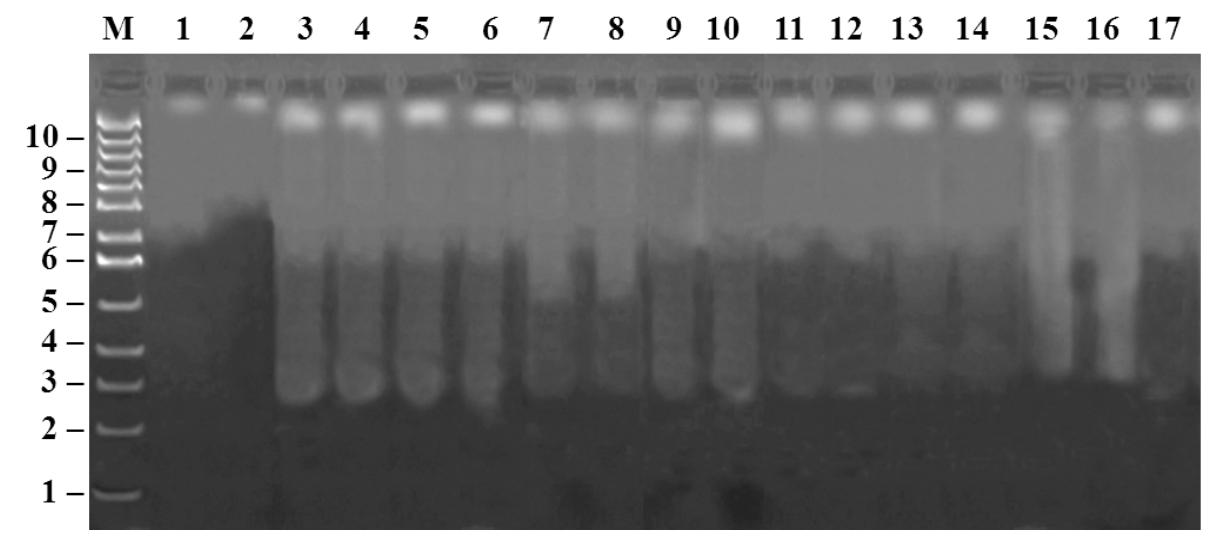

Figure 1. Gel electrophoresis $1 \% \mathrm{w} / \mathrm{v}$ agrose of untreated and treated DNA. Lane M: Molecular weight marker (left side); Lane 1: Untreated nucleic acid; Lane 2: DMSO treated nucleic acid (negative control); Lane 3: Methotrexate treated nucleic acid (positive control); Lanes 4-17: Compounds (8a-d, 7, 9a, b, 11, 5a-f) treated nucleic acid.

\subsection{Biological Evaluation}

The newly synthesized compounds were subjected to nucleic acid binding assay using agarose gel electrophoresis method.

\section{Nucleic Acids Binding Assay}

Different synthetic drugs induced DNA damage was evaluated by measuring the level of genomic DNA fragmentation and detecting DNA ladders on agarose gel electrophoresis (Figure 1). Compared with the vehicle control group (lane 2 negative control and lane 3 positive control), there was no significant change in genomic DNA fragmentation in some treated groups. There were major differences in the response of extracted DNA (from Lanes 4-17 in Figure 1). It is possible that drugs exert its effect solely by indirect mechanisms. This contrast may have been due to different enzyme(s) being with differing susceptibilities to drugs.

\section{Conclusion}

Our results describe a simple and efficient method for the synthesis of different novel fused uracils. Heteroannulation on the C-5 of uracil usually requires forcing conditions and complex synthetic pathways. Our synthetic compounds concern with the reactions of uracils with different benzylideneaniline, araldehydes and ninhydrin which have a biological screen.

\section{Acknowledgements}

The authors wish to thank Dr. Yassin El-Ayouty, professor of Microbiology, Botany and Microbiology Department, Faculty of Science, Zagazig University, Zagazig, Egypt, for carrying out the biological activities of the new synthesized compounds.

\section{References}

[1] Brown, D.J. (1984) Pyrimidines and Their Benzo Derivatives. Comprehensive Heterocyclic Chemistry, 3, 57-155. http://dx.doi.org/10.1016/B978-008096519-2.00035-7

[2] Wamhoff, H., Dzenis, J. and Hirota, K. (1992) Uracils: Versatile Starting Materials in Heterocyclic Synthesis. Advances in Heterocyclic Chemistry, 55, 129-259. http://dx.doi.org/10.1016/S0065-2725(08)60222-6

[3] González-Vallinas, M., Molina, S., Vicente, G., de la Cueva, A., Vargas, T., Santoyo, S., García-Risco, M.R., Fornari, T., Reglero, G. and de Molina, A.R. (2013) Antitumor Effect of 5-Fluorouracil Is Enhanced by Rosemary Extract in Both Drug Sensitive and Resistant Colon Cancer Cells. Pharmacological Research, 72, 61-68. http://dx.doi.org/10.1016/j.phrs.2013.03.010

[4] Innominato, P.F., Lévi, F.A. and Bjarnason, G.A. (2010) Chronotherapy and the Molecular Clock: Clinical Implications in Oncology. Advanced Drug Delivery Reviews, 62, 979-1001. http://dx.doi.org/10.1016/j.addr.2010.06.002 
[5] Isanbor, C. and O’Hagan, D. (2006) Fluorine in Medicinal Chemistry: A Review of Anti-Cancer Agents. Journal of Fluorine Chemistry, 127, 303-319. http://dx.doi.org/10.1016/j.jfluchem.2006.01.011

[6] Muzzalupo, R., Tavano, L. and La Mesa, C. (2013) Alkyl Glucopyranoside-Based Niosomes Containing Methotrexate for Pharmaceutical Applications: Evaluation of Physico-Chemical and Biological Properties. International Journal of Pharmaceutics, 458, 224-229. http://dx.doi.org/10.1016/j.ijpharm.2013.09.011

[7] Wu, Z.Q., Shah, A., Patel, N. and Yuan, X.D. (2010) Development of Methotrexate Proline Prodrug to Overcome Resistance by MDA-MB-231 Cells. Bioorganic Medicinal Chemistry Letters, 20, 5108-5112. http://dx.doi.org/10.1016/j.bmcl.2010.07.024

[8] Pectasides, D., Pectasides, E., Papaxoinis, G., Xiros, N., Kamposioras, K., Tountas, N. and Economopoulos, T. (2010) Methotrexate, Paclitaxel, Ifosfamide, and Cisplatin in Poor-Risk Nonseminomatous Germ Cell Tumors. Urologic Oncology: Seminars and Original Investigations, 28, 617-623. http://dx.doi.org/10.1016/j.urolonc.2008.10.013

[9] Banerjee, D., Mayer-Kuckuk, P., Capiaux, G., Budak-Alpdogan, T., Gorlick, R. and Bertino, J.R. (2002) Novel Aspects of Resistance to Drugs Targeted to Dihydrofolate Reductase and Thymidylate Synthase. Biochimica et Biophysica Acta (BBA)—Molecular Basis of Disease, 1587, 164-173. http://dx.doi.org/10.1016/S0925-4439(02)00079-0

[10] Mackey, J.R., Baldwin, S.A., Young, J.D. and Cass, C.E. (1998) Nucleoside Transport and Its Significance for Anticancer Drug Resistance. Drug Resistance Updates, 1, 310-324. http://dx.doi.org/10.1016/S1368-7646(98)80047-2

[11] Marques, S.M., Enyedy, E.A., Supuran, C.T., Krupenko, N.I., Krupenko, S.A. and Santos, M.A. (2010) Pteridine-Sulfonamide Conjugates as Dual Inhibitors of Carbonic Anhydrases and Dihydrofolate Reductase with Potential Antitumor Activity. Bioorganic \& Medicinal Chemistry, 18, 5081-5089. http://dx.doi.org/10.1016/j.bmc.2010.05.072

[12] Mauritz, R., Peters, J., Priest, D.G., Assaraf, Y.G., Drori, S., Kathmann, I., Noordhuis, P., Bunni, M.A., Rosowsky, A., Schornagel, J.H., Pinedo, H.M. and Jansen, G. (2002) Multiple Mechanisms of Resistance to Methotrexate and Novel Antifolates in Human CCRF-CEM Leukemia Cells and Their Implications for Folate Homeostasis. Biochemical Pharmacology, 63, 105-115. http://dx.doi.org/10.1016/S0006-2952(01)00824-3

[13] Gangjee, A., Adair, O. and Queener, S.F. (1999) Pneumocystis carinii and Toxoplasma gondii Dihydrofolate Reductase Inhibitors and Antitumor Agents: Synthesis and Biological Activities of 2,4-Diamino-5-methyl-6-[(monosubstituted anilino)methyl]pyrido[2,3-d]pyrimidines. Journal of Medicinal Chemistry, 42, 2447-2455. http://dx.doi.org/10.1021/jm990079m

[14] Elnagdi, M.H., Al-Awadi, N. and Erian, A.N. (1996) In Compensative Heterocyclic Chemistry II. In: Katritzky, A.R., Rees, C.W. and Scriven, E.F.V., Eds., Pergamon Press, Oxford, 431-488.

[15] Rashad, A.E., Mahmoud, A.E. and Ali, M.M. (2011) Synthesis and Anticancer Effects of Some Novel Pyrazolo[3,4-d]pyrimidine Derivatives by Generating Reactive Oxygen Species in Human Breast Adenocarcinoma Cells. European Journal of Medicinal Chemistry, 46, 1019-1026. http://dx.doi.org/10.1016/j.ejmech.2011.01.013

[16] Elnagdi, M.H., Elmoghayar, M.R.H. and Elgemeie, G.F. (1987) Chemistry of Pyrazolo-Pyrimidines. Advances in Heterocyclic Chemistry, 41, 319-376. http://dx.doi.org/10.1016/S0065-2725(08)60164-6

[17] Zatloukal, M., Jorda, R., Gucký, T., Řezníčková, E., Voller, J., Pospíšil, T., Malínková, V., Adamcová, V., Kryštof, V. and Strnad, M. (2013) Synthesis and in Vitro Biological Evaluation of 2,6,9-Trisubstituted Purines Targeting Multiple CyclinDependent Kinases. European Journal of Medicinal Chemistry, 61, 61-72. http://dx.doi.org/10.1016/j.ejmech.2012.06.036

[18] Kumar, A., Sinha, S. and Chauhan, P.M. (2012) Synthesis of Novel Antimycobacterial Combinatorial Libraries of Structurally Diverse Substituted Pyrimidines by Three Component Solid Phase Reactions. Bioorganic Medicinal Chemistry Letters, 12, 667-669. http://dx.doi.org/10.1016/S0960-894X(01)00829-0

[19] Baraldi, P.G., Pavani, M.G., Nunez, M., Brigid, P., Vitali, B., Gambari, R. and Romagnoli, R. (2002) Antimicrobial and Antitumor Activity of $n$-Heteroimmine-1,2,3-dithiazoles and Their Transformation in Triazolo-, Imidazo-, and Pyrazolopirimidines. Bioorganic Medicinal Chemistry, 10, 449-456. http://dx.doi.org/10.1016/S0968-0896(01)00294-2

[20] Nasr, M.N. and Gineinah, M.M. (2002) Pyrido[2, 3-d]pyrimidines and Pyrimido[5',4':5, 6]pyrido[2, 3-d]pyrimidines as New Antiviral Agents: Synthesis and Biological Activity. Archiv der Pharmazie, 335, 289-295. http://dx.doi.org/10.1002/1521-4184(200208)335:6<289::AID-ARDP289>3.0.CO;2-Z

[21] Nagarapu, L., Vanaparthi, S., Bantu, V. and Kumar, C.G. (2013) Synthesis of Novel Benzo[4,5]thiazolo[1,2- a]pyrimidine-3-carboxylate Derivatives and Biological Evaluation as Potential Anticancer Agents. European Journal of Medicinal Chemistry, 69, 817-822. http://dx.doi.org/10.1016/j.ejmech.2013.08.024

[22] Sondhi, S.M., Johar, M., Rajvanshi, S., Dastidar, S.G., Shukla, R., Raghubir, R., et al. (2001) Anticancer, Antiinflammatory and Analgesic Activity Evaluation of Heterocyclic Compounds Synthesized by the Reaction of 4-Isothiocyanato4-methylpentan-2-one with Substituted o-Phenylenediamines, o-Diaminopyridine and (Un)Substituted o. Australian Journal of Chemistry, 54, 69-74. http://dx.doi.org/10.1071/CH00141

[23] Youssif, S. and Assy, M. (1996) Fervenulin, 4-Deazafervenulin and 5-Deazaalloxazines Analogue: Synthesis and An- 
timicrobial Activity. Journal of Chemical Research, 442, 2546.

[24] Herrmann, M., Lorenz, H.M., Voll, R., Grünke, M., Woith, W. and Kalden, J.R. (1994) A Rapid and Simple Method for the Isolation of Apoptotic DNA Fragments. Nucleic Acids Research, 22, 5506-5507. http://dx.doi.org/10.1093/nar/22.24.5506

[25] Ishikawa, I., Itoh, T., Melik-Ohanjanian, R.G., Takayangi, H., Mizunc, Y. and Ogura, H. (1990) Synthesis and X-Ray Analysis of 1-Benzyl-6-chlorouracil. Heterocycles, 31, 1641-1646. http://dx.doi.org/10.3987/COM-90-5472

[26] Cresswell, R.M. and Wood, H.C.S. (1960) The Biosynthesis of Pteridines. Part I. The Synthesis of Riboflavin. Journal of the Chemical Society, 4768-4775.

[27] Youssif, S. and Pfleiderer, W. (1998) Purines XIV.[1]. Reactivity of 8-Bromo-3,9-dimethylxanthine towards Some Nucleophilic Reagents. Journal of Heterocyclic Chemistry, 35, 949-954. http://dx.doi.org/10.1002/jhet.5570350428

[28] Youssif, S. (1997) DMF Acetals as Alkylating and Cyclizing Agents: A Facile Route to Substituted Pyrazolo[3,4-d] pyrimidine-4,6(5H,7H)-diones. Chemical Monthly, 128, 493-501. http://dx.doi.org/10.1007/BF00806857

[29] Hutzenlaub, W. and Pfleiderer, W. (1979) Purines, XIII. Simplified Syntheses of 7-Methy- and 1,7-Dimethylxanthines and Uric Acids. Liebigs Annalen der Chemie, 1847-1854.

[30] Youssif, S. (2004) 6-Aminouracil as Precursors for the Synthesis of Fused Di- and Tricyclic Pyrimidines. Journal of Chemical Research, 341-343.

[31] Youssif, S. and Ageli, F. (2008) One-Pot Synthesis of Fused 2-Thiouracils: Pyrimidopyrimidines, Pyridopyrimidines and Imidazolopyrimidines. Zeitschrift für Naturforschung, 63b, 860-864.

[32] Peet, N.P., Huber, E.W. and Huffman, J.C. (1995) Reaction of Ninhydrin with $\beta$-Dicarbonyl Compounds. Journal of Heterocyclic Chemistry, 32, 33-41. http://dx.doi.org/10.1002/jhet.5570320106

[33] Prabhakar, K.R., Veerapur, V.P., Bansal, P., Vipan, K.P., Reddy, K.M., Barik, A., Reddy, B.K.D., Reddanna, P., Priyadarsini, K.I. and Unnikrishnan, M.K. (2006) Identification and Evaluation of Antioxidant, Analgesic/Anti-In- flammatory Activity of the Most Active Ninhydrin-Phenol Adducts Synthesized. Bioorganic \& Medicinal Chemistry, 14, 7113-7120. http://dx.doi.org/10.1016/j.bmc.2006.06.068

[34] Klumpp, D.A., Fredrick, S., Lau, S., Jin, K.K., Bau, R., Prakash, G.K.S. and Olah, G.A. (1999) Acid-Catalyzed Condensations of Ninhydrin with Aromatic Compounds. Preparation of 2,2-Diaryl-1,3-indanediones and 3-(Diarylmethylene)isobenzofuranones. The Journal of Organic Chemistry, 64, 5152-5155. http://dx.doi.org/10.1021/jo990197h

[35] Ruttink, J. (1946) Investigations in the Purine Series. II. Synthesis of Some Purine Derivatives. Recueil des Travaux Chimiques, 65, 751-767. http://dx.doi.org/10.1002/recl.19460651007

[36] Blicke, F.F. and Godt, H.C. (1954) Reactions of 1,3-Dimethyl-5,6-diaminouracil. Journal of the American Chemical Society, 76, 2798-2800. http://dx.doi.org/10.1021/ja01639a058

[37] Bredereck, H. and Edenhofer, A. (1955) Synthesen in der Purinreihe, VI. Mitteil. ${ }^{1)}$ : Synthesen mit 4- und 5-Aminouracil. Chemische Berichte, 88, 1306-1312. http://dx.doi.org/10.1002/cber.19550880825 